\title{
METALLURGICAL AND TECHNOLOGICAL INVESTIGATION WITH EXPERIMENTAL ARCHAEOMETALLURGICAL REPRODUCTION OF A LOMBARD BRONZE BUCKLE FROM NORTH ITALY
}

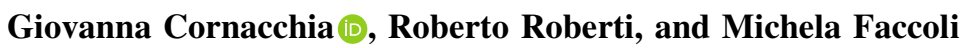 \\ Department of Mechanical and Industrial Engineering, University of Brescia, Via Branze 38, 25123 Brescia, Italy
}

\section{Andrea Breda}

Soprintendenza Archeologia, Belle Arti e Paesaggio per le Provincie di Bergamo e Brescia, Piazza Giovanni Labus 3, 25121 Brescia, Italy

\section{Alessandro Pacini}

Goldsmith, Via di Totona 35, Montepulciano, Italy

Copyright (C) 2020 The Author(s)

https://doi.org/10.1007/s40962-020-00518-y

\begin{abstract}
A metallurgical and technological characterization of a seventh century bronze buckle coming from the Lombard necropolis of Monte San Zeno in Montichiari (Brescia, northern Italy) was performed to understand the manufacturing techniques. At first, a careful inspection was carried out to highlight the existence of any type of details, which would indicate an intentional design activity or typical casting defects. To avoid destructive measures on
\end{abstract}

the ancient artifact, the buckle was successively characterized only via scanning electron microscopy coupled with energy-dispersive $X$-ray spectroscopy. This investigation was supported by an accurate study on the chemical composition of the matrix. The results suggest that the buckle was produced by sand casting, although the use of this technique in Europe dates back to the fifteenth century. Finally, based on the results obtained, a faithful archaeometallurgical reproduction of the buckle is proposed. 


\section{Graphic Abstract}

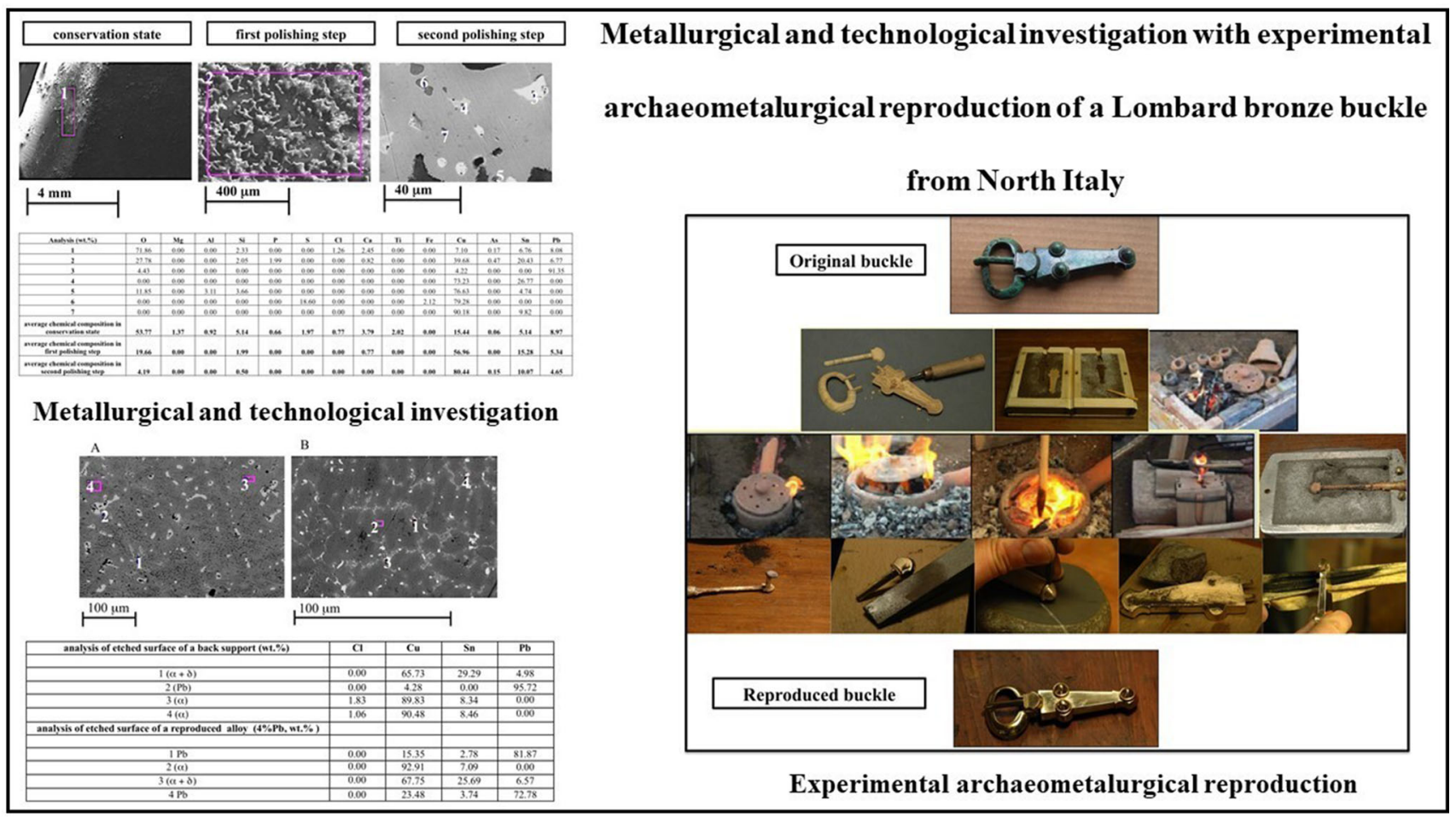

Keywords: Lombards, buckle, archaeometallurgy, bronze, SEM-EDS

\section{Introduction}

The Lombards, also Langobards or Longbeards (from lang long + bart beard), were well-known Germanic tribes, establishing a kingdom in Italy, the Regnum Langobardorum, which endured for more than two centuries. ${ }^{1}$ At the end of the eighth century, Paolo Diacono in his Historia Langobardorum provided the historical and semilegendary guide to the Lombards' Scandinavian origin and their subsequent migrations. By the end of the fifth century, they moved from their base on the River Elbe through Bohemia and Moravia to Lower Austria. Later, they spread in two stages (in 526 and 546) into northern and southern Pannonia (western Hungary) and from there in 568 invaded Italy. Between 570 and 605, they defeated most of the northern regions and controlled large areas of central and southern Italy. The capital of their kingdom was Pavia, whereas Brescia, Verona, Cividale, Trento, Spoleto and Benevento were some of the most important urban-based dukedoms. The Lombard kingdom became a power of European relevance between the seventh and the beginning of the eighth century, and then, its decline began. Lombards' rule in the north was curtailed in 774 through conquest by the Frankish king Charlemagne. However,
Lombard nobles continued to rule southern parts of Italy well into the eleventh century, when they were conquered by the Normans and their territories annexed to the County of Sicily. The settlements of Lombards are well documented by extensive cemeteries discovered both in northern and central Italy, for example: Testona and Momo (Piemonte), Montichiari, Calvisano, Leno, Goito (Lombardia), Cividale (Friuli) Nocera Umbra (Umbria) and Castel Trosino (Marche). The excavations revealed grave goods testifying the survival and evolution of manufactures from Pannonia and to the progressive adoption of Mediterranean styles and motifs. These findings also proved the maintenance of a strongly militarized society, with parade equipment as emblems of the elite. It is worth noting that in the epigraphs of the sixth-seventh century, death is considered a place of rest, a sleep awaiting awakening that requires a wealth of objects to be buried following a ritual celebrated in the family. The body of the deceased was prepared and dressed, sometimes wrapped in the shroud, exposed to visits with gifts required by the social role and economic position exercised by the deceased. The necropolis of Monte San Zeno in Montichiari (Figure 1) is one of the largest early medieval cemetery complexes in the district of Brescia, in North 


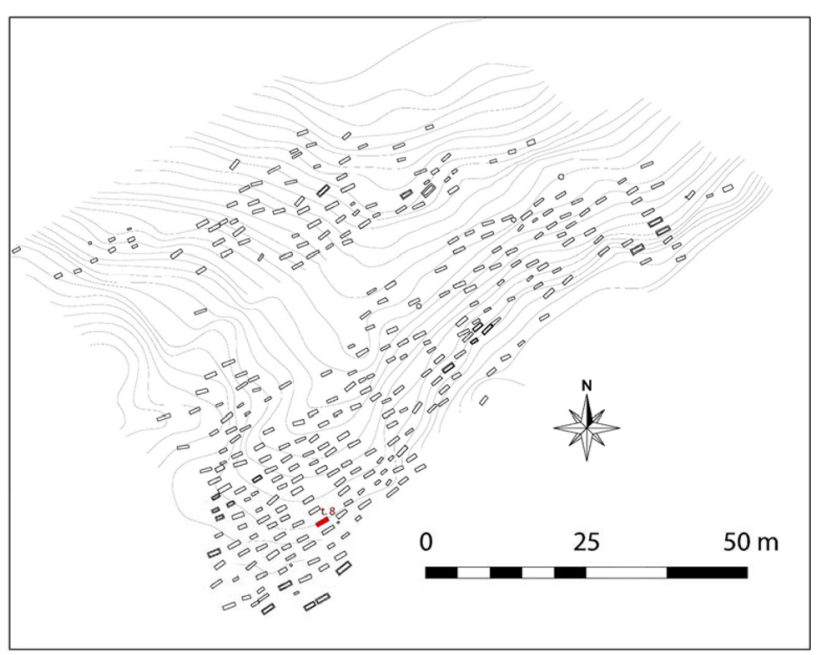

Figure 1. Planimetry of Monte San Zeno necropolis with grave n. 8 (t. 8) in red.

Italy. ${ }^{2}$ It is situated on the slopes of the outermost cordon of the glacial moraine of Lake Garda near an ancient road which connected Montichiari to the settlements of the north and south skirting the Chinese river bed. The site belonged to a seventh-century village, probably situated in the neighboring valley. Since 1998, more than 300 graves, laid out in parallel lines, have been excavated in an area of about $6000 \mathrm{~m}^{2}$. Seventy-nine burials contained over 300 findings, which can be divided into six main groups according to their function: blades, metal accessories for belts and leather straps, metal items of clothing and ornaments, nonmetal items of clothing and ornaments, toiletries, tools for domestic and daily use, respectively. The male tombs, especially in the oldest nucleus of the cemetery, contained cast bronze accessories for weapon belts derived from the Roman military culture. These belts supported weapons and other items such as leather bags, small knives and bone combs. The bronze accessories are paired with a robust iron dagger (scramasax) only in two graves of the cemetery (graves n. 8 and n. 44). The weapon belts were a symbol of the deceased's social status and belonging to a class that was distinguished by functions (probably public functions of royal delegation), characterized by a medium-high spending capacity. In Montichiari, this class differed from the aristocracy which had much richer and more lavish grave goods. The debate on the origins of these bronze belt buckles is still open, and some researchers believe they are of Roman tradition, whereas others suppose a Germanic production, inspired by the military culture of limes (Rhine-Danubian border of the Western Roman Empire) of the late ancient age. ${ }^{3}$ However, recent studies found close analogies between these sets and those of burials in the cemeteries of the Avars in Pannonia. Hungarian researchers affirm that the deceased buried with these belts probably were Lombard officials at the service of the Avar Khagan. ${ }^{3}$ The weapon belt accessories were derived from a standardized production which is characterized by excellent workmanship. ${ }^{4}$ They are widespread throughout Lombard Italy, especially the north, and were mass-produced by qualified workshops that had a wide range of product distribution. Among the bronze belt accessories, a buckle rediscovered in the grave n. 8 (Figure 2) is the object of the investigation presented in this paper. Scanning electron microscope equipped with energy-dispersive X-ray spectroscope (SEM-EDS) was used to reveal the composition of the buckle. Size measurements and a careful technological investigation were also carried out on the buckle. The combined application of these methods was an effective tool to understand the manufacturing process of the examined artifact. Eventually, the buckle was reproduced following the ancient technique.

\section{Artifact Description and Experimental Methods}

The investigated buckle (Figure 3a), included in the collection of Soprintendenza Archeologia Belle Arti e Paesaggio di Bergamo e Brescia (codename 148250a), comes from the grave n. 8 of the necropolis of Monte San Zeno in Montichiari (Lombardy, Italy) and is dated to the first half of the to the seventh century. This object was used in the male belts to carry the scramasax, a typical sturdy knife, which was very common for the Lombard population (but also for Frankish, Alemanni and other western Germanic
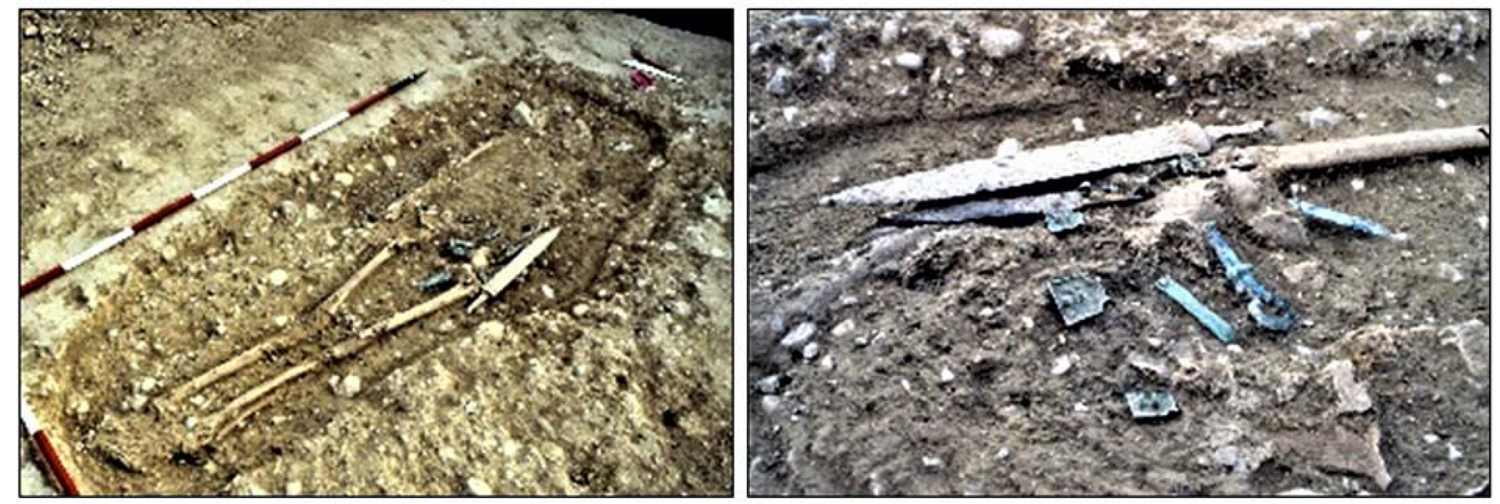

Figure 2. Grave n. 8 in Monte San Zeno necropolis with a detail of the grave goods. 


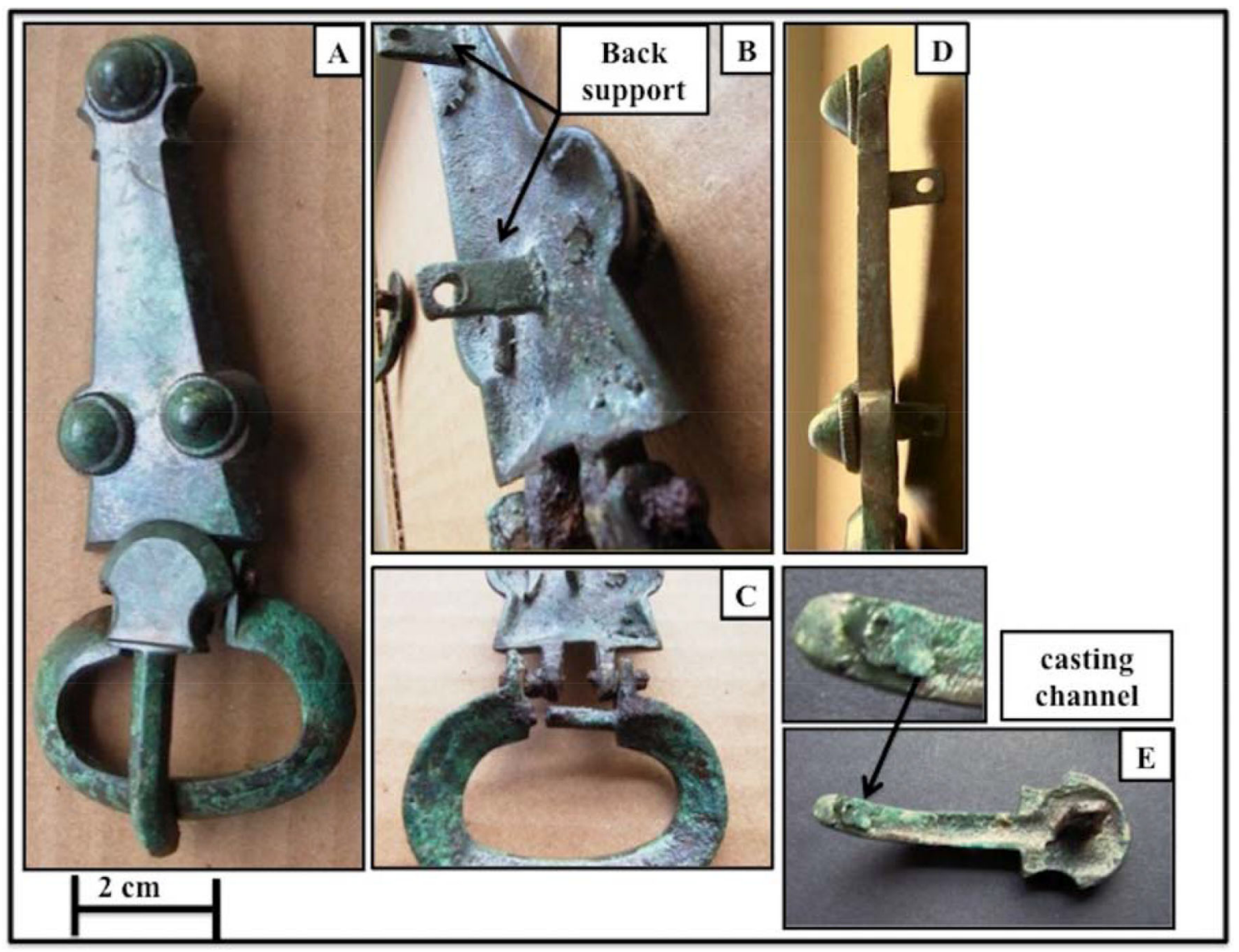

Figure 3. Different views of the seventh century buckle (Codename 148250a-Collection of Soprintendenza Archeologia Belle Arti e Paesaggio di Bergamo e Brescia). In particular, it is possible to note: (a) the investigated buckle; (b) the backside of the buckle; (c) oval bracket with an iron pin to hold the tongue; (d) lateral profile of the buckle where the thickness and details of the three hemispherical studs with a decorated crown can be observed; (e) a tongue ending in a shield shape.

populations stationed in the territories of the former provinces of the kingdom). In fact, similar daggers have been found in several sites (between the end of the seventh and the eighth century) in Lombard Italy. ${ }^{5-8}$ The upper surface of the buckle appears cleaned and was recovered in a wellpreserved condition, but there is no information about possible consolidation or protection with restoration products. On the surface, a thin brown-green uniform and adherent layer is highlighted. On the backside, the surface is very irregular and rough (Figure $3 b$ ). The buckle measures $11 \mathrm{~cm}$ in length, $6 \mathrm{~mm}$ in height and a maximum width of $4.5 \mathrm{~cm}$.

In particular, it is noted that the buckle is obtained by the assembly of different elements. The main buckle body has a triangular longitudinal section with a rounded end; furthermore, there is an oval bracket with dimensions of $4.5 \times 3.5 \mathrm{~cm}$ (Figure 3c), a tongue ending in a shield shape (Figure 3e), held in place by an iron pin and three hemispherical studs with a decorated crown of a $12 \mathrm{~mm}$ diameter (Figure 3a, d). This weapon belt accessory is derived from a standardized production characterized by excellent workmanship.,

The chemical composition and the characterization of the microstructural aspects of the buckle were determined via energy-dispersive X-ray spectroscopy (EDS), using a LEO EVO-40 XVP scanning electron microscope (SEM) both using the secondary-electron and backscattered electron detector modes.

SEM observations have been particularly important in the characterization of the archaeological item because this analysis could obtain information without destructive tests; for this investigation, it was stated to proceed step by step by analyzing the buckle in its current conservation state and successively after two polishing steps. The removal of oxidization from a small area of the object is accomplished using a commercial tarnish remover. This procedure could verify the presence of contaminating elements or oxides that can derive either from the restoration (i.e., a layer of Paraloid) or from the burial ground. Finally, a micro- 
polished area was chemically etched with an alcoholic solution of ferric chloride $\left(\mathrm{FeCl}_{3}\right)$, in order to identify the phases resulted from the manufacturing procedure.

\section{Results and Discussion}

\section{Preliminary Macro-observations}

A feature that immediately appears evident on eye inspection is that the buckle is made of a copper-rich alloy. The morphology of the all-front parts is well finished, while the backside shows a grainy surface. This last aspect is compatible with objects produced with a sand casting technique. In addition, the large number of similar buckles found suggests that it may be some kind of mass production, compatible with this technology.

To better understand, the sand casting technique utilizes destructible sand molds to form complex metal geometries. The sand casting process involves the use of a furnace, metal, pattern and sand mold. The metal is melted in the furnace and then ladled and poured into the cavity of the sand mold, which is formed by the pattern. The sand mold separates along a parting line, and the solidified casting can be removed. It is important to properly design the gating system with channels in the mold to prevent porosity and to obtain correct filling and solidification of the final object. ${ }^{10}$ A residual part of one of these casting channels is clearly visible on the lower side of the tongue end (Figure 3e).

From the literature, ${ }^{10-13}$ the use of this technique in Europe dates back to the fifteenth century, respect to the lost wax casting technique already discovered in the Late Bronze Age, where a number of highly elaborated bronze objects were made using this technique. ${ }^{14}$ It is worthwhile to note that in China, the sand casting technique with the use of clay molds is dated about 1600-1000 BC with the Shang Dynasty (construction of Houmuwu ding in 1300 BC). In Assyria, the Sennacherib king (704-681 BC) built a massive bronze casting of up to 30 tons using clay molds rather than the lost wax method. ${ }^{15}$

These first observations suggest the hypothesis that the production method of the Lombard bronze buckle is a sand casting technique. The validation of the hypothesis that the local metallurgists were aware of the sand casting technique in this site and in this period could bring the knowledge of this technique also in Italy and Europe at least in the seventh century.

The most likely scenario is that the prototypes were drawn with a compass and any metric system was employed to calculate multiples and submultiples of measures. Once obtained, the model was then copied. Historical evidences have revealed that the unit of measurement at that time was the Liutprando Foot which in Pavia equaled $0.4432 \mathrm{~m}$, in a duodecimal-base system, and it matches the Roman Cubit 14.15. The Liutprando palm (corresponding to $1 / 4$ of Liutprando Foot) equals to $110.8 \mathrm{~mm}$, the total length of the buckle.

It is hard to determine the proportionality of the measures considering that from the prototype to the final product may occur shrinking phenomena and that a single model would be copied several times and probably in different scalar sizes. The total measure of the buckle is more likely proving the metric system employed in Pavia. ${ }^{16,17}$

\section{SEM/EDS Analysis}

Semiquantitative chemical analyses were carried out both as overall phases average and as spots within each particular, to gather reliable data about all the major constituents. It is important to remind the limits of the instrument with light elements, such as oxygen, so the content of these elements is semiquantitative and will be used as a relative comparison between the various polishing steps. Considering the great amount of data that has been collected, the discussion of the results will be limited to the most significant examples. All EDS results are expressed as a percentage weight.

\section{Back Support}

This back support fixed the buckle to the belt. It involves two flat perpendicular bars to the central body with two perfectly spherical holes at their ends, probably obtained with cold perforation in the final stages of the buckle manufacturing (Figure 3b). The surface morphology is essentially the same as all over the rest of the back face of the buckle, granular with some scratches and dark spots uniformly distributed.

In Figure 4 are reported some representative images, and the EDS analyses as carried out in the three conditions: current conservation state, first and second polishing steps.

In view of the discussion that will follow, it is worth quoting that the examined analyses are discussed considering both point analyses and average analyses of the different areas studied (reported in the last lines of the table in Figure 4) as estimated from the analytical data.

While observing the analyses, it can be noted that already in the state of conservation, it is evident that the buckle material is constituted by bronze alloy, in particular the $\mathrm{Cu}-\mathrm{Sn}-\mathrm{Pb}$ system. In this first stage of the investigation, the analyses are not representative of the chemical composition of the alloy because the surface is contaminated by many oxides/pollutants based on $\mathrm{Al}, \mathrm{Si}, \mathrm{P}, \mathrm{Ca}, \mathrm{Fe}$ that can be connected to the burial environment. In some cases, 

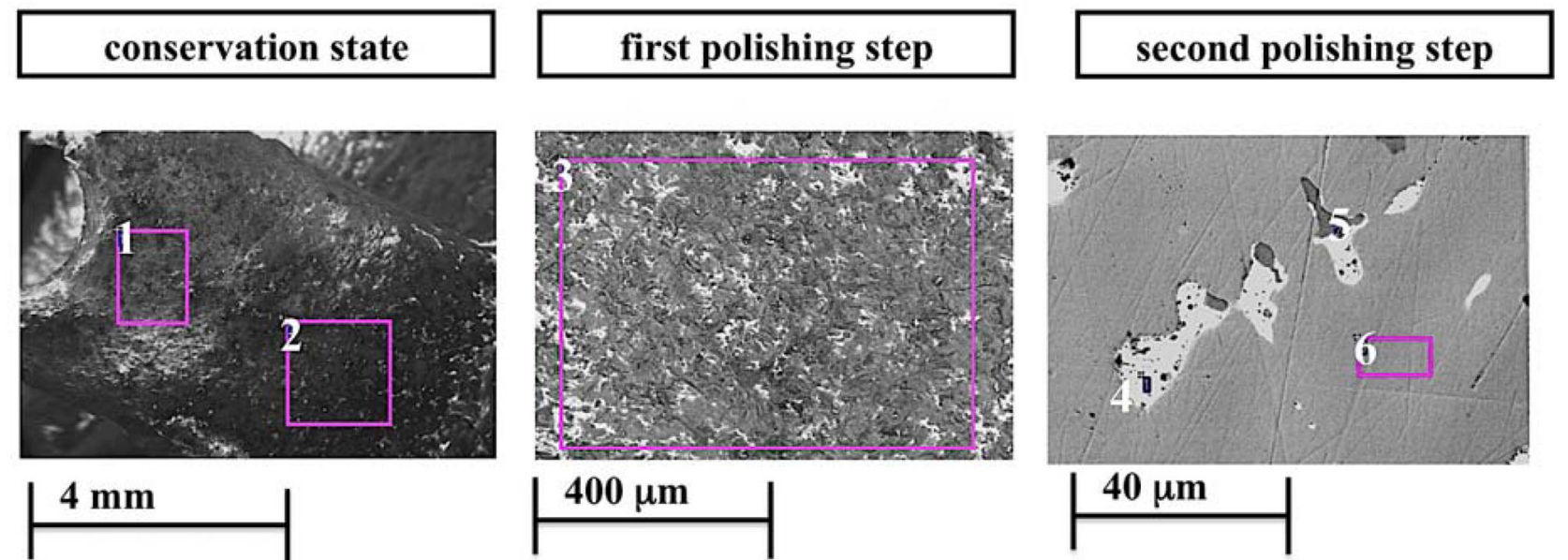

\begin{tabular}{|c|c|c|c|c|c|c|c|c|c|c|c|c|}
\hline Analysis (wt.\%) & o & $\mathrm{Al}$ & Si & $\mathbf{P}$ & S & $\mathrm{Ca}$ & $\mathrm{Ti}$ & $\mathrm{Fe}$ & $\mathrm{Cu}$ & As & Sn & $\mathrm{Pb}$ \\
\hline 1 & 38.89 & 1.79 & 5.59 & 3.75 & 0.00 & 3.12 & 0.00 & 2.64 & 16.14 & 0.00 & 17.65 & 10.42 \\
\hline 2 & 42.52 & 2.30 & 3.73 & 2.89 & 0.00 & 4.06 & 0.00 & 1.51 & 16.32 & 0.00 & 14.80 & 11.88 \\
\hline 3 & 30.89 & 2.41 & 1.56 & 2.04 & 3.35 & 1.47 & 0.00 & 0.00 & 32.15 & 0.00 & 16.71 & 9.42 \\
\hline 4 & 0.00 & 0.00 & 0.00 & 0.00 & 0,00 & 0.00 & 0.00 & 0.00 & 5.13 & 0.00 & 0.00 & 94.87 \\
\hline 5 & 39.88 & 0.00 & 0.51 & 0.39 & 0.00 & 0.57 & 0.00 & 0.00 & 45.19 & 0.12 & 10.28 & 3.07 \\
\hline 6 & 25.41 & 0.00 & 0.90 & 0.63 & 0.00 & 0.00 & 0.00 & 0.00 & 57.50 & 0.00 & 10.99 & 4.84 \\
\hline $\begin{array}{c}\text { average chemical composition in } \\
\text { conservation state }\end{array}$ & 40.71 & 2.05 & 4.66 & 3.32 & 0.00 & 3.59 & 0.00 & 2.08 & 16.23 & 0.00 & 16.23 & 11.15 \\
\hline $\begin{array}{l}\text { average chemical composition in } \\
\text { first polishing step }\end{array}$ & 32.38 & 1.41 & 1.23 & 2.26 & 2.33 & 1.37 & 0.00 & 0.00 & 29.74 & 0.00 & 19.04 & 10.26 \\
\hline $\begin{array}{l}\text { average chemical composition in } \\
\text { second polishing step }\end{array}$ & 5.75 & 0.00 & 0.70 & 0.00 & 0.00 & 0.00 & 0.00 & 0.00 & 78.25 & 0.08 & 10.23 & 5.00 \\
\hline
\end{tabular}

\section{Figure 4. Some representative SEM micrographs and analyses (wt\%) carried out in current conservation state, first and second polishing steps of back support.}

large quantities of $\mathrm{Pb}$ and traces of As were found, probably linked to the alloy. In other analyses, high $\mathrm{S}$ levels were found (about $20-22 \%$ by weight), probably related to a copper sulfide restoration product, used to create antique patinas on bronze and to homogenize the restorer interventions with the rest of the artifact, making it more uniform.

Analyses after the first polishing step still present impurity elements, such as oxygen, contaminating the chemical composition of the alloy. For this reason, a second polishing was carried out. After the second polishing step, the oxygen and external elements content drastically decreased and it was possible to estimate the chemical composition of the alloy, which appears to be close to a bronze with $\mathrm{Cu}$ contents around $80-85 \%$, Sn from 8 to $10 \%$ and $\mathrm{Pb}$ from 4 to $6 \%$. Also, the yellow-gold color of the buckle confirms that the percentage of $\mathrm{Sn}$ is between 5 and $10 \%$, in fact the color of the bronze varies with the $\mathrm{Cu}-\mathrm{Sn}$ composition, passing from the red copper when $\mathrm{Sn}$ content is of about $5 \%$, yellow-gold for Sn between 5 and 10\%, light yellow for $\mathrm{Sn}$ between 10 and $25 \%$ up to white for $\mathrm{Sn}>25 \%$. $^{18}$

The same small area, previously polished, was subsequently subjected to chemical etch. All the micrographs show a structure typical for cast tin bronze. The situation is clearly depicted in Figure 5a, where it is possible to observe the alloy microstructure. Metallographic analysis shows a granular structure consisting of two phases with a different $\mathrm{Cu} / \mathrm{Sn}$ ratio and a regular distribution of approximately spherical lead globules. Lead is practically insoluble in solid copper, and it solidifies last as almost pure metal in the grain boundaries.

The identified alloy $(\mathrm{Sn}<13.9 \%)$ remains in the field of $\alpha$ phase, which is a substitution solid solution, in the $\mathrm{Cu}-\mathrm{Sn}$ phase diagram.

Due to the nature of copper-tin alloys, at the practical cooling rates from the melting temperature, alloys with $\mathrm{Sn}$ contents of less than $13 \%$ exhibit considerable segregation phenomena (coring phenomena). This causes high composition gradients within the grains, already with Sn contents of 5\% their central portions being rich in copper, surrounded by zones increasingly rich in tin. The last solidified zones will be so rich in Sn to solidify as $\alpha+\delta$ phases, which, according to the phase diagram, should be present only in alloys with more than $13.9 \%$ of Sn. In summary, the microstructure consists of $\alpha$ dendrites and $\alpha+\delta$ eutectoid between the dendrites.

This mechanism explains the presence of two phases with a different $\mathrm{Cu} / \mathrm{Sn}$ ratio: One is the $\alpha$ phase, with lower $\mathrm{Sn}$ contents, while the other, found in small quantities, is the $\alpha+\delta$ phase that has higher Sn amount. ${ }^{18-22}$ 
A

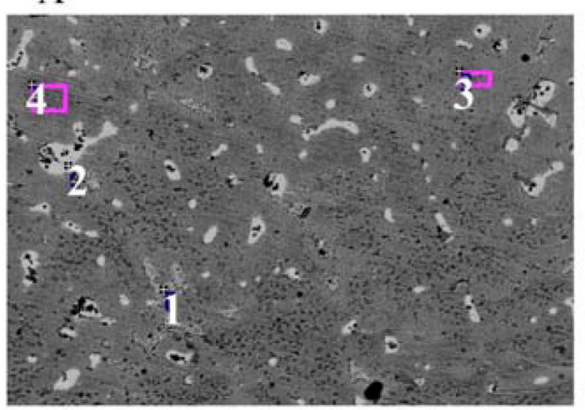

$100 \mu \mathrm{m}$
B

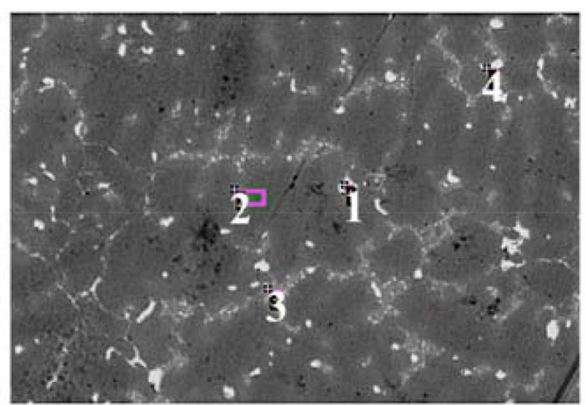

$100 \mu \mathrm{m}$

\begin{tabular}{|c|c|c|c|c|}
\hline analysis of etched surface of a back support (wt.\%) & $\mathrm{Cl}$ & $\mathrm{Cu}$ & Sn & $\mathrm{Pb}$ \\
\hline $1(\alpha+\delta)$ & 0.00 & 65.73 & 29.29 & 4.98 \\
\hline $2(\mathrm{~Pb})$ & 0.00 & 4.28 & 0.00 & 95.72 \\
\hline $3(\alpha)$ & 1.83 & 89.83 & 8.34 & 0.00 \\
\hline $4(\alpha)$ & 1.06 & 90.48 & 8.46 & 0.00 \\
\hline \multicolumn{5}{|l|}{ analysis of etched surface of a reproduced alloy $(4 \% \mathrm{~Pb}, w t . \%)$} \\
\hline $1 \mathrm{~Pb}$ & 0.00 & 15.35 & 2.78 & 81.87 \\
\hline $2(\alpha)$ & 0.00 & 92.91 & 7.09 & 0.00 \\
\hline $3(\alpha+\delta)$ & 0.00 & 67.75 & 25.69 & 6.57 \\
\hline $4 \mathrm{~Pb}$ & 0.00 & 23.48 & 3.74 & 72.78 \\
\hline
\end{tabular}

Figure 5. Microstructure of the back support (a) and of the archaeometallurgical alloy reproduced with $4 \%$ of $\mathrm{Pb}$ (b). Alcoholic solution of ferric chloride $\left(\mathrm{FeCl}_{3}\right)$ etch.

It is worthwhile to note that there is no change in $\mathrm{Pb}$ particle shape at the end of the solidification; this is an important aspect suggesting that the buckle was not obtained by plastic deformation.

To verify these considerations, various similar alloys with $\mathrm{Pb}$ content from 4 to $12 \%$ were reproduced with archaeometallurgical methods. An example is shown in Figure 5b. It is possible to observe that the reproduced alloy with about $4 \% \mathrm{~Pb}$ has the same phases, although the microstructure of the back support is coarser.

\section{Buckle Body}

To analyze this part of the buckle without damaging it, it was agreed to polish only a small area of the curvilinear border (see Figure 2a). Some examples of a thorough structural investigation conducted in this area are reported in Figure 6. The results achieved are in line with the analyses obtained for the back support. In particular, passing from the state of conservation to the second polishing step, the decrease in oxygen and impurities is confirmed.

The observations made on the sample in the last polishing step report the same alloying elements content identified for the back supports, confirming the use of the same type of bronze.
In this case, it was not possible to use the chemical etch to highlight the microstructure but, observing the analysis from 4 to 7 in the table of Figure 5, the alloying elements content reflects that of the various phases identified in the back support, namely $\alpha, \alpha+\delta$, Pb particles, and still some traces of surface contaminants such as oxides and copper sulfide.

\section{Hemispherical Studs with Decorated Crown}

The three hemispherical studs were fixed on the triangular base bending the stem after insertion into the three holes on the buckle surface. Probably, the stem of the studs was bent and then hammered.

A further clue on the structural aspects of this buckle element comes from the details of the carved decoration, visible in imaged at higher magnification in the SEM micrographs in Figure 7.

The studs are the only elements of the buckle that have an engraved decoration. In particular, there are a series of small parallel notches on the crown probably made with a chisel.

Observing the base of a single stud (Figure 7a), it is possible to notice the presence of evident gas cavities. These porosities are further important information on the 

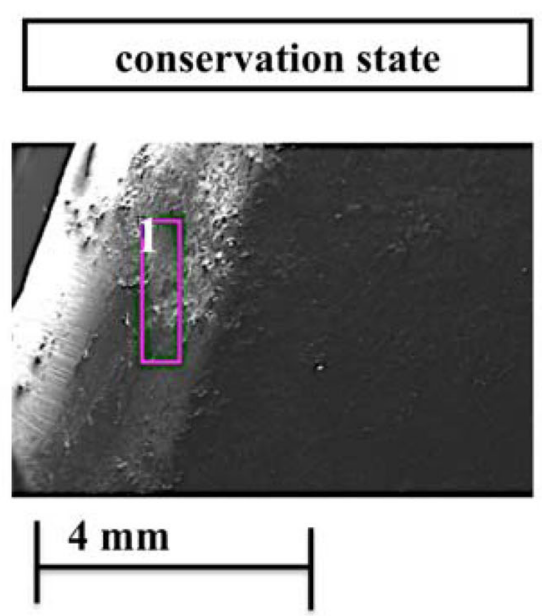

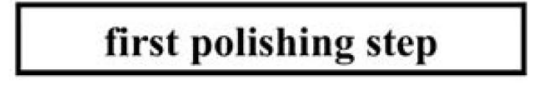

second polishing step
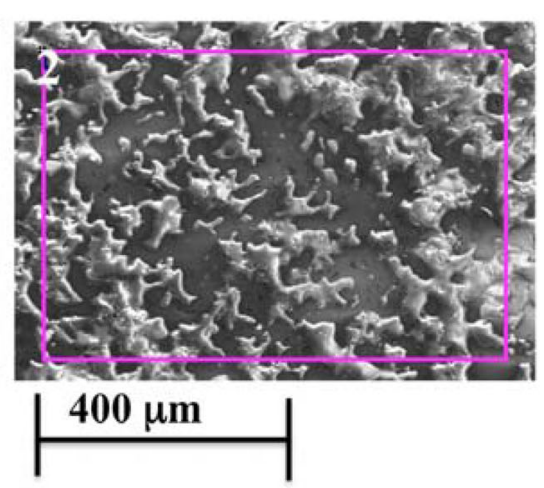
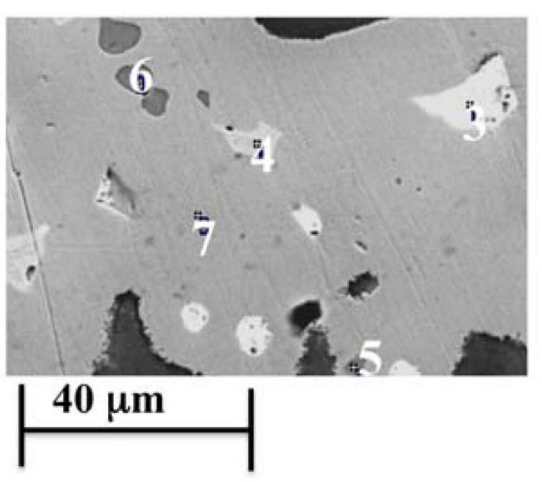

\begin{tabular}{|c|c|c|c|c|c|c|c|c|c|c|c|c|c|c|}
\hline Analysis (wt.\%) & o & $\mathbf{M g}$ & Al & $\mathrm{Si}$ & $\mathbf{P}$ & $s$ & $\mathrm{Cl}$ & $\mathrm{Ca}$ & $\mathrm{Ti}$ & $\mathrm{Fe}$ & $\mathrm{Cu}$ & As & Sn & $\mathrm{Pb}$ \\
\hline 1 & 71.86 & 0.00 & 0.00 & 2.33 & 0.00 & 0.00 & 1.26 & 2.45 & 0.00 & 0.00 & 7.10 & 0.17 & 6.76 & 8.08 \\
\hline 2 & 27.78 & 0.00 & 0.00 & 2.05 & 1.99 & 0.00 & 0.00 & 0.82 & 0.00 & 0.00 & 39.68 & 0.47 & 20.43 & 6.77 \\
\hline 3 & 4.43 & 0.00 & 0.00 & 0.00 & 0.00 & 0.00 & 0.00 & 0.00 & 0.00 & 0.00 & 4.22 & 0.00 & 0.00 & 91.35 \\
\hline 4 & 0.00 & 0.00 & 0.00 & 0.00 & 0.00 & 0.00 & 0.00 & 0.00 & 0.00 & 0.00 & 73.23 & 0.00 & 26.77 & 0.00 \\
\hline 5 & 11.85 & 0.00 & 3.11 & 3.66 & 0.00 & 0.00 & 0.00 & 0.00 & 0.00 & 0.00 & 76.63 & 0.00 & 4.74 & 0.00 \\
\hline 6 & 0.00 & 0.00 & 0.00 & 0.00 & 0.00 & 18.60 & 0.00 & 0.00 & 0.00 & 2.12 & 79.28 & 0.00 & 0.00 & 0.00 \\
\hline 7 & 0.00 & 0.00 & 0.00 & 0.00 & 0.00 & 0.00 & 0.00 & 0.00 & 0.00 & 0.00 & 90.18 & 0.00 & 9.82 & 0.00 \\
\hline $\begin{array}{l}\text { average chemical composition in } \\
\text { conservation state }\end{array}$ & $\mathbf{5 3 . 7 7}$ & 1.37 & 0.92 & 5.14 & 0.66 & 1.97 & 0.77 & 3.79 & 2.02 & 0.00 & 15.44 & 0.06 & 5.14 & 8.97 \\
\hline $\begin{array}{l}\text { average chemical composition in } \\
\text { first polishing step }\end{array}$ & 19.66 & 0.00 & 0.00 & 1.99 & 0.00 & 0.00 & 0.00 & 0.77 & 0.00 & 0.00 & 56.96 & 0.00 & 15.28 & 5.34 \\
\hline $\begin{array}{l}\text { average chemical composition in } \\
\text { second polishing step }\end{array}$ & 4.19 & 0.00 & 0.00 & 0.50 & 0.00 & 0.00 & 0.00 & 0.00 & 0.00 & 0.00 & 80.44 & 0.15 & 10.07 & 4.65 \\
\hline
\end{tabular}

Figure 6. Some representative SEM micrographs and analyses carried out in the current conservation state, first and second polishing steps of the buckle body.

technique used, in fact these defects are typical in casting. Once again, this particular one favors production with the technique of sand casting.

The most likely hypothesis is that the stem of the stud should be the casting channel, successively transformed into a fixing nail by hammering.

\section{Archaeometallurgical Reconstruction of the Buckle Following the Sand Casting Process}

The laboratory investigations and the emerged considerations have led to the possibility to faithfully reproduce the original buckle (Figures 3a and 8p) with the hypothesized sand casting technique by archaeometallurgical practice. For this purpose, a pair of wooden molding boxes, foundry sand and some tools were used, such as brushes, spatulas for shaping, smoothing devices, and small casting channels (Figure 8a, b). Below the different phases of the experimental procedure are described; in Figure 8 are visible some pictures of its fundamental passages.

Briefly, for molding boxes preparation, initially the foundry sand was pressed and flattened inside one of the molding boxes; then, talc was used as a mold release agent, and the model was imprinted in the sand up to half of its thickness. Then, the casting channels and the vents were prepared, and the second molding box filled with wellpressed sand was placed. Further, the molding boxes were separated and the model was removed obtaining the negative shape of the buckle (Figure $8 b$ ). Finally, the two molding boxes were closed, and the melted bronze (Figure $8 \mathrm{c}-\mathrm{f}$ ) was poured carefully into the mold cavities, which, once filled, were then allowed to cool (Figure 8g).

Foundry sands were prepared following ancient recipes. $^{10,11}$ In particular, Biringuccio ${ }^{10}$ describes two types of foundry sands: One is used "in fresco", meaning it is used still humid, and the other is used "cotta" one, what means it is used after fire heating.

It is important to underline what has been already considered: the properties of foundry sands, such as refractory properties, cohesion and plasticity as well as permeability and mechanical resistance to the impact of molten metal.

Thanks to the documentary sources study, two final recipes were tried.

The main difference is represented by the ingredients composing the damp part of the recipes; in fact, in the first case water was used, fat in the second one. The foundry 


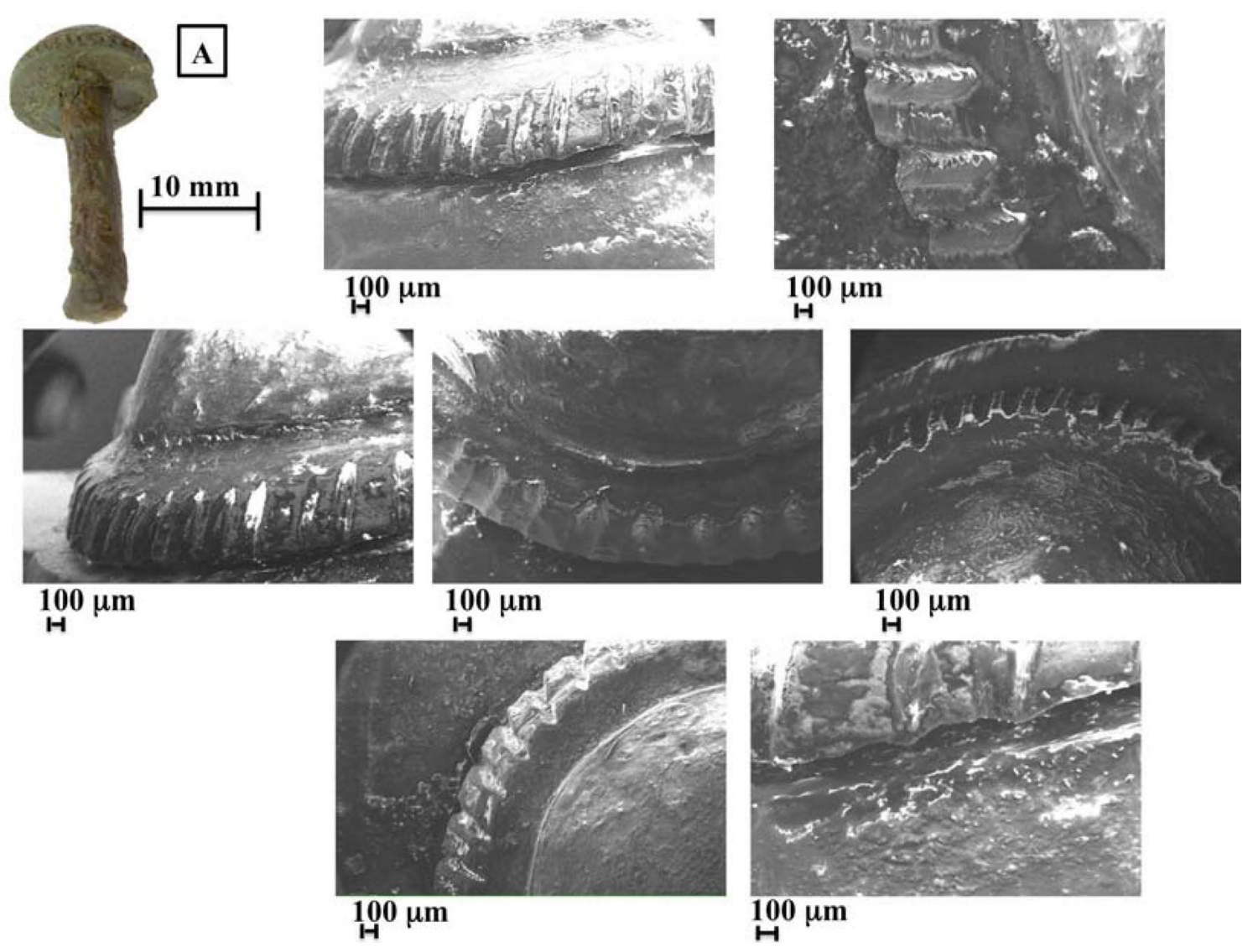

Figure 7. Different SEM views of the hemispherical studs with decorated crown.

sands with the presence of water need to be heated to dry before melting, while those with the presence of fat can be used directly without drying.

It is important to highlight that in the case of the first recipe, the damp part could be either a simple water, or a solution saturated with water and salt. Often prescribed, it was called "maestra", because after cooking, it hardened the sand making it more resistant to the metal impact. For this purpose, the usage of vinegar, urine and wine was also possible.

The recipes were a mixture of:

- $\quad$ siliceous sand with very fine grain;

- clay to facilitate the modeling;

- refractory additives such as iron oxide flake and pumice powder;

- binding additives of animal (i.e., pig fat) or vegetable (i.e., residual ash from laundry washing) origin to increase plasticity (only in the second recipe);

- Porosity additives such as coal dust and soot;

- The damp part (i.e., fat or water/solution of water and salt).

Concerning the various parts of the buckle model (the oval bracket, the main buckle body, the three studs without the stems, the tongue with shield decoration), olive wood was chosen (Figure 8a). The casting channels and vents placements considered filling the shapes without contacting cosmetic surfaces to avoid excessive finishing work after casting; in addition, where possible, casting channels have been transformed into parts of the buckle.

In particular, for the oval bracket a rectangular wooden channel was placed on the curvature of the arch. The casting was realized vertically to maximize the gravity force.

Concerning the main buckle body, the casting channels were realized with wooden sticks with the same shape and thickness as the original back supports.

After the shape realization in the sand, two through-holes were performed with wooden sticks in the right places on the original buckle. These holes are served by vents during casting, and they also produced the back supports, perpendicular to the plate, after casting. Finally, the three holes for the studs' connections were made with three wooden sticks fixed in the foundry sand: During casting, the molten bronze carbonizes them to leave the holes on the main buckle body after casting. Also, this part of the buckle has been cast vertically, using the two hooks for connection to the belt as a casting channel. 


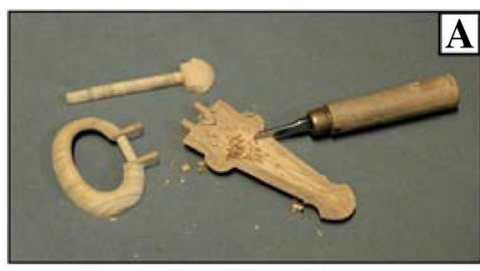

A - Wood carving of the buckle components, for this purpose burins and small gauges have been employed.

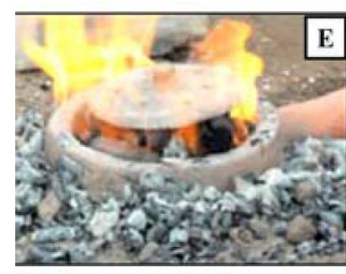

E - Detail of the melting inside the ceramic furnace.

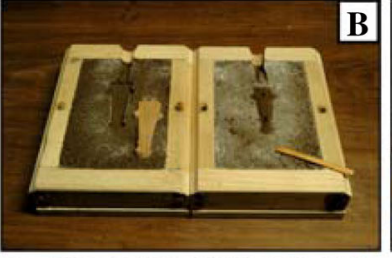

B - The wooden flasks have been filled with ancient type of moulding sand: its composition has been derived from renaissance recipes and subsequently modified according to the available raw materials.

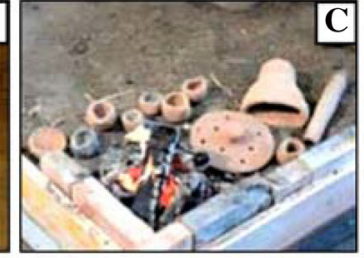

C - Reconstruction with natural crucibles and of the entire furnace, its metal casting components and vent pipes. partially refined clay of the

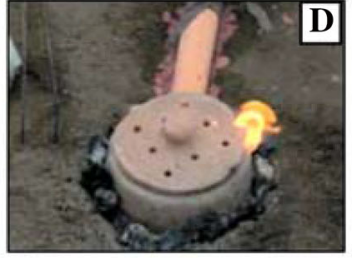

D - The Cylindrical furnace with perforated lid it's fuelled with charcoal and the air is manually blown with leather vents.

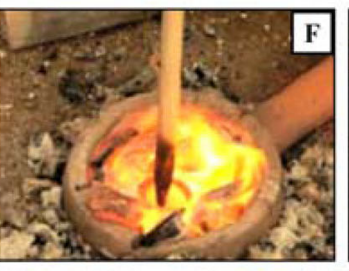

F - The small crucible containing the bronze alloy just before the extraction from the ceramic furnace.

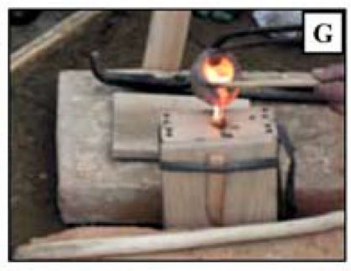

G - Liquid alloy casting inside the flasks kept closed by leather ties

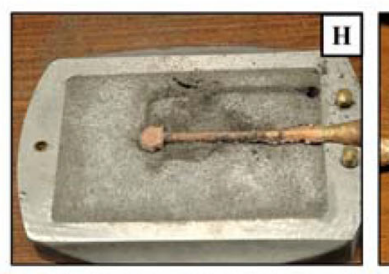

H - First casting attempt with fluvial silica sand, supplemented with a little clay and charcoal powder moistened with salted water. In this case a manufactured with a decorating pennant along with its back tab for the buckle hinging. buckle tongue has been
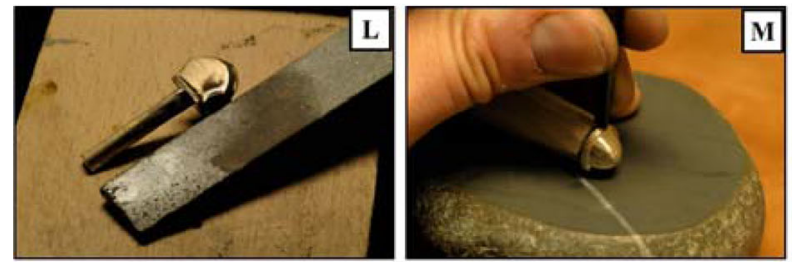

L - The final tongue, sanding has $\mathrm{M}$ - Decoration made with a sharp been performed with fine-grained hammered chisel of the studs' edges. sandstone.

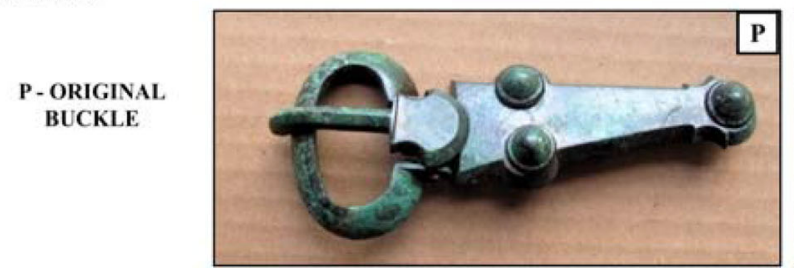

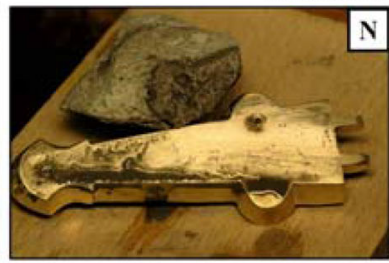

$\mathrm{N}$ - Prepolishing of the buckle body with pumice stone

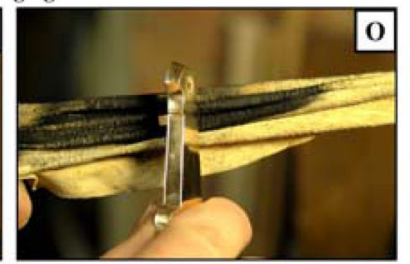

O - Polishing of the buckle body rubbing it on a leather cloth dusted with abrasive powder

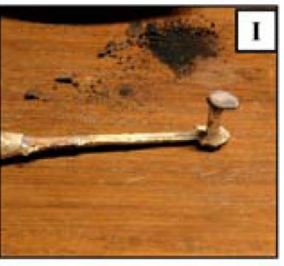

I - Back view of the tongue: the hinging tab has been obtained by casting and has been used as venting channel.

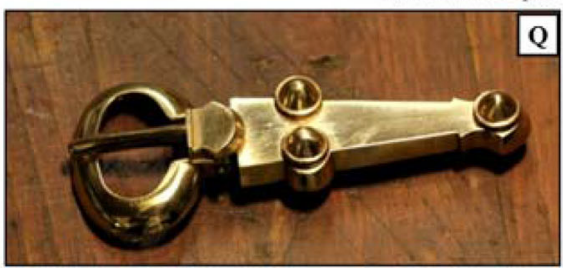

\section{Q - REPRODUCED} BUCKLE

\section{Figure 8. Some of the fundamental passages of the buckle experimental reproduction.}

The three studs, instead, were cast horizontally utilizing a thin lateral vent; the small casting channel became the stem of the stud thanks to the properties of the alloy used which, in addition to having good casting characteristics, is also machinable by hammering (Figure $8 \mathrm{~m}$ ).

Even the lower surface of the reproduced studs had gas porosities similar to those noted on the original one (Figure $7 \mathrm{a}$ ), confirming this gating system for the original studs.

The tongue with shield decoration has also been cast with a vertical system, exploiting its elongated shape (Figures 8i, 1).

On the backside of the shield of the original tongue, there is a short-perforated bar that serves for fixing. Also, this bar was obtained with the same bars system of the buckle main body.

Two bronze alloys were chosen in the range of chemical composition obtained with the laboratory analyses, in particular the first alloy with $\mathrm{Cu} 85 \%, \mathrm{Sn} 10 \%, \mathrm{~Pb} 5 \%$ and the second one with $\mathrm{Cu} 87 \%, \mathrm{Sn} 9 \%, \mathrm{~Pb} 4 \%$. Both alloys gave good results, especially the second one that has a lower amount of porosity. The alloys were cast in the coal oven and cast at a temperature of $1080-1100{ }^{\circ} \mathrm{C}$.

Once all the parts had been made, the casting channels were separated with a chisel and the top surfaces were filed to remove the fusion skin and any roughness.

After filing, finishing can be carried out using sandstone pieces, water and subsequently pumice stone. 
The crown decoration on the studs was realized with a small chisel (Figure 8n, o).

The end of the tongue was slightly bent, and the final polishing of all pieces was carried out with leather and abrasive powders. Finally, the buckle was assembled (Figure 8q).

\section{Conclusions}

Engineering research applied to the cultural heritage is an expanding field in Italy driven from the rich historical and metallurgical legacy present in the territory. While most of the efforts are devoted to the technologies for cultural heritage conservation and preservation, recently, several metallurgical researchers have devoted efforts to the study of ancient manufacturing technologies..$^{6,23-26}$ The interest in the medieval manufacturing techniques is growing in view of the peculiarities that have been found as, for example, in bronze artifacts, particularly relevant in the Lombard culture (as well as in other western Germanic populations, where also silver or gold examples were rediscovered). The studied buckle, used for the male belts on which the scramasax was hung, is a very common Lombard object, especially in northern Italy, whereas it was rarer in central-southern Italy. This suggested a commercial channel opened with the Avars of Pannonia. The large number of similar buckles found suggests that, during this time period, it reached a form of mass serialized production. Based on the macroscopic observations, a manufacturing procedure is proposed: All parts of the buckle were obtained by casting, separately finished and finally assembled. The visual inspection, especially the back of the buckle, leads to the hypothesis of the use of sand casting technique. The large number of similar buckles found, and their detailed design are compatible with sand casting technology and suggest that they were planned to be cast into a bivalve matrix.

SEM-EDS analysis showed that the alloy used is a bronze with an average chemical composition of $\mathrm{Cu}$ contents around $80-85 \%$, Sn from 8 to $10 \%$ and $\mathrm{Pb}$ from 4 to $6 \%$ and the microstructure is consistent with the use of sand casting.

The experimental analysis and the subsequent reconstruction of the buckle have enabled to ascertain an excellent technical level of the artisans who produced the buckle and the good knowledge of the sand casting, to avoid any kind of welding and to reduce the subsequent machining of the obtained objects.

The bronze alloy was certainly selected to meet the artisans requirements, with good performances in the casting phase, but workable with a hammer; perhaps the craftsmen also cared about its color.
This work on the Lombard buckle demonstrates indirect evidence for the use of sand casting before the fifteenth century that evidence is the sand casting traces left on the artifact.

The study of the artifact from a technological and metallurgical point of view is very important. This approach can demonstrate, as in this case, how the type of artifact construction presupposes the process of sand casting as logical.

Probably, further studies and observations on archaeological findings will highlight a more widespread usage in antiquity of sand casting than it has been believed.

\section{Acknowledgements}

The authors are grateful for the historical information given by Dr. Paola Marina De Marchi, Former Director of the Archaeological area of Castelseprio (Arsago Seprio, Italy).

\section{Funding}

Open access funding provided by Università degli Studi di Brescia within the CRUI-CARE Agreement. This work was supported by scientific convention between University of Brescia and Soprintendenza Archeologia, Belle Arti e Paesaggio per le province di Bergamo e Brescia (Project Title: "Analysis and study of the metal finds production techniques of the Longobard age: collaboration for training, research and development on awareness raising activities on the Lombard heritage of the Province of Brescia”).

Conflict of interest The authors declare that they have no conflict of interest.

Open Access This article is licensed under a Creative Commons Attribution 4.0 International License, which permits use, sharing, adaptation, distribution and reproduction in any medium or format, as long as you give appropriate credit to the original author(s) and the source, provide a link to the Creative Commons licence, and indicate if changes were made. The images or other third party material in this article are included in the article's Creative Commons licence, unless indicated otherwise in a credit line to the material. If material is not included in the article's Creative Commons licence and your intended use is not permitted by statutory regulation or exceeds the permitted use, you will need to obtain permission directly from the copyright holder. To view a copy of this licence, visit http://creativecommons. org/licenses/by/4.0/.

\section{REFERENCES}

1. P.J. Crabtree, Medieval Archaeology: An Encyclopedia (Garland Publishing, Inc., New York, 2001), pp. 301-303

2. A. Breda, Montichiari (Bs). Monte S. Zeno. Necropoli longobarda e insediamenti medievali. The Journal of Fasti Online, published by the Associazione 
Internazionale di Archeologia Classica, Roma (2007), http://www.fastionline.org/docs/FOLDER-it-2007-76. pdf

3. P.M. De Marchi, L.S. Zopfi, Cassano d'Adda (MI) e Montichiari (BS): sepolture con manufatti selezionati, significato sociale e circolazione di prodotti, in Proceedings of the international Conference Le necropoli longobarde in Italia. Indirizzi della ricerca e nuovi dati (Trento, 26-28 settembre 2011), p 118-136 (2014)

4. A. Breda, Longobardi nel bresciano (Gli insediamenti di Montichiari, Fondazione Civiltà Bresciana, Brescia, 2007)

5. E. Possenti, Necropoli longobarde in Italia: lo stato della ricerca, in Proceedings of the International Conference Le necropoli Longobarde in Italia. Indirizzi della ricerca e nuovi dati (Trento, 26-28 settembre 2011), pp. 35-43 (2014)

6. S. Gialanella, E. Possenti, D. Chateigner, Materials and technological aspects of gilded buckles from a North Eastern Medieval Italian context. Appl. Phys. A 113, 1101-1108 (2013). https://doi.org/10.1007/ s00339-013-7753-9

7. C. Giostra, La struttura sociale nelle necropoli longobarde italiane: una lettura archeologica. In: Archeologia dei Longobardi: dati e metodi per nuovi percorsi di analisi, Proceedings of I Incontro per l'Archeologia barbarica (Milano, 2 maggio 2016). Archeologia Barbarica (1). S.A.P. Società Archeologica, Mantova, pp. 83-112, (2017). ISBN 978-88-99547-12-7

8. C.W. Ammen, The complete handbook of sand casting, Tab books, 1-238 (1979)

9. O. von Hessen, I ritrovamenti barbarici nelle collezioni civiche veronesi del Museo di Castelvecchio, Verona, Museo di Castelvecchio, pp. 39-67 (1968)

10. A.Carugo, De la pirotechnia of Vannoccio Biringuccio, I-II-III-IV-V chapter, pp. 118-123(1977)

11. G. Pomaro, Fondo Palatino della Biblioteca Nazionale di Firenze, Pal.934.I e Pal.1000, pp 169-170 (1991)

12. M.A.A. Khan, A.K. Sheikh, B.S. Al-Shaer, Evolution of Metal Casting Technologies: A Historical Perspective. (Springer New York, 2017) cap 2, pp. 2-6

13. F.W. Thackeray, J.E. Findling, Events That Formed the Modern World: From the European Renaissance through the war of terror. (Ed. Abc-Clio Inc, New edizione, 2012) p. 226

14. A.F. Harding, European Societies in the Bronze Age (Harding A. F., Cambridge University Press, Cambridge, 2004), pp. 225-226

15. S. Dalley, The Mystery of the Hanging Garden of Babylon: An Elusive World Wonder Traced, Oxford University Press. ISBN 978-0-19-966226-5. Translation by the author, reproduced by permission of Oxford University Press (2013)
16. C. Inglese, A. Ippolito, Conservation, Restoration, and Analysis of Architectural and Archaeological Heritage Inglese (IGI Global, Pennsylvania, 2018), pp. 358-360. https://doi.org/10.4018/978-1-52257555-9

17. B. Pomi, il Piede di Liutprando, antica unità di misura di origine longobarda, extracted to Estratto dai Quaderni del Club Ingegneri milanesi - oltre il 1992, N. 5 (1998) (https://www.liutprand.it/articoliPavia. asp?id=171)

18. E. Gianotti, Rame e sue Leghe, Classificazioni e trattamenti termici di. Trattamenti Termici Ferioli \& Gianotti S.p.A. Torino 17, https://www.gianottielio.it/ syntax_files/tbl_documenti_allegato_ita_id_docu mento45.pdf

19. M. Cavallini, G.E. Gigante, De Re Metallica-Dalla produzione antica alla copia moderna. Ed. l'Erma di Bretschneider collana studia archaeologica 69 (2007)

20. G.L. Garagnani, F. Piasentini, G. Venturi Pagani Cesa, Caratterizzazione microstrutturale e meccanica di leghe di rame da fonderia per applicazioni artistiche. La Metallurgia Italiana, 1/2006, 39 (2006)

21. J. Thomson, R. Zavadil, M. Sahoo, Development of a lead-free bearing material for aerospace applications. Inter Metalcast 4, 19-30 (2010). https://doi.org/10. 1007/BF03355483)

22. A. Garbacz-Klempka, S. Wilk, J.S. Suchy, Analysis of eneolithic copper jewellery artifacts from Książnice Cemetery in South Poland. Inter Metalcast 11, 366-370 (2017). https://doi.org/10.1007/s40962-0160065-z

23. G. Cornacchia, M. Faccoli, R. Roberti, Metallurgical investigation of a steel Miner's Chisel from Ponte Val Gabbia III Site. JOM 67, 260-271 (2015)

24. G. Tonelli, M. Faccoli, R. Gotti, R. Roberti, G. Cornacchia, Historical and metallurgical characterization of a "falchion" sword manufactured in Caino (Brescia, Italy) in the early 17th century A.D. JOM 68, 2233-2249 (2016)

25. P. Matteis, G. Scavino, Mechanical performance of historical wrought iron rods. Archaeometry 61, 1053 (2019)

26. G. Cornacchia, R. Roberti, M. Faccoli, Characterization and technological origin identification of ancient iron nails. JOM (2020). https://doi.org/10.1007/ s11837-020-04121-8

Publisher's Note Springer Nature remains neutral with regard to jurisdictional claims in published maps and institutional affiliations. 